\title{
Forms and Mechanisms of Regional Cooperation between the Eurasian Economic Union Countries in the Field of Social Security
}

\author{
Amangeldy Sh. Khamzin \\ Innovative University of Eurasia, Republic of Kazakhstan
}

Yermek A. Buribayev*

Institute of Law and Economics, Kazakh National Pedagogical University named after Abay Republic of Kazakhstan; Corresponding Email: ermek_a@rambler.ru

Zhanar T. Karasheva

Saulegul Yermukhametova

Al-Farabi Kazakh National University, Republic of Kazakhstan

Alfiya R. Vorivodina

Kazakhstan Institute of Innovation and Telecommunication Systems West Kazakhstan engineering-humanitarian university, Republic of Kazakhstan

Doi:10.5901/mjss.2015.v6n6s7p56

\section{Abstract}

Article focuses on the trends and characteristics of regional cooperation of the Eurasian Economic Union (EAEU) in the field of social security. The main purpose of this work is the development of guidelines of a system of regional cooperation in the field of social security and the mechanisms for its implementation, which would be acceptable to all member countries of the Union. As a result of a comprehensive analysis, the authors define the necessity of enhancing regional cooperation in the sphere of joint social development of the EAEU using the forms and mechanisms of integration based on respect for international standards of social rights. The conclusions are made that the effects of the international social and legal norms through provisions of national laws is indirect and requires coordination with national standards. Lack of a single act in the EAEU, which brings together the main regional social and legal norms, the elasticity of the source base of regional social rights and the lack of a clear hierarchy of norms of international law, do not contribute to the effectiveness and implementation of the principles of EAEU.

Keywords: social security, social rights, Eurasian Economic Union

\section{Introduction}

Eurasian Economic Union (EAEU) was established to ensure the free movement of goods, services, capital and labor, as to unsure coordinated, coherent and unified policy in the sectors of the economy. The EAEU is an international organization of regional economic integration, which has its own international legal personality. Freedom of movement of capital and labor inevitably determines the occurrence of the problems of social security of workers in the territories of the Member States of the Union, the responsibility of employers for social security and pensions. The differences in the levels and forms of social protection of workers, citizens of EAEU are contrary to the principle of the harmonization of the conditions of social and labor rights within the Union.

Social security is one of the most sensitive areas of responsibility of the state, because it determines the level of life, trust in public institutions, and the development prospects. The integration of regional entities places the joint responsibility on the member states for ensuring the social rights of the individual, as well as the transformation of the international standards of social rights in the supranational legislation.

Problem statement of this research is determined by several factors: the relatively high level of integration between the countries of the EAEU; active migration, including labor migration; lack of harmonization of national legislation in the 
field of social protection; inefficiency of the control system over the implementation of state obligations in the field of social rights; low efficiency of social norms; lack of adequate financial and organizational support to the generally accepted social standards at the national level. Thus, formation of modern scientific concept of development of the regional cooperation of the EAEU countries in the field of social security is an urgent problem, the solution of which largely contributes to the formation of the EAEU as a socially-oriented regional integration association.

\section{Regional Cooperation and Integration}

The issues of regional cooperation and integration in the CIS and EurAsEC are thoroughly studied by a number of scholars, whose research has been presented in monographs and articles (e.g. see Frohwein, 2004; Lagutina, 2014; Khamzin, 2009; Sharkov, 2004). Researchers focus on describing the process of integration at the international level, the development of the legal framework, availability of malfunctions in the work of integration structures of the region. The issues of interaction of EAEU today acquired a special urgency and a genuine interest in the world. Before our eyes the new integration association is created and began to operate, claiming to occupy the leading position in the region and globally. Launch of a comprehensive integration in all spheres of vital interests of the countries of the EAEU requires an adequate, high-quality scientific analysis, advice and suggestions elaborated by expert community.

Existing studies of regional associations of the former Soviet Union presented in the work of scientists from different disciplines: economic, historical, political, legal orientation (e.g. Linn \& Tiomkin, 2005; Kanunnikov, 2014; Moiseev, 2001; Shumilov, 2008). A number of studies deal with specific aspects of regional cooperation and integration (e.g. Abbott et al, 2006; Costea, 2005; Langenhove et al, 2006; Velyaminov, 2004; Mishalchenko, 2004; Tikhomirov, 1996; Khamzina \& Khamzin, 2009; Chernichenko, 1999). The legal status of the Commonwealth of Independent States and the international legal framework of cooperation of the CIS countries have been discussed in detail by Moiseev (2001). Research of Sharkov (2004) deal with the current situation and development prospects of the CIS. Bogolyubova, Nikolaeva and Pshenko (2005) focus on international humanitarian cooperation, while Shumilov (2007) studies labor and migration cooperation in the CIS. Aspects of social and labor rights in the integration associations in the post-Soviet space is well elaborated by Khamzin (2009). These works and other works related with the countries (republics) of the former Soviet Union and their emergence in the political, economic and social terms, the need for economic associations and steps in this direction, cause considerable scientific interest nowadays.

However, it should be stated that the public relations arising out of international cooperation at the regional level in the field of social protection of the population have not been studied as a promising area of scientific analysis. This is despite the fact that it is the regional cooperation of states in the social sphere, the fundamental objectives of which is to improve the well-being of people, the social and economic stability, warranty of social rights, aims to ensure global security. System of mechanisms of EAEU cooperation in the field of social security has not been an object of complex analysis previously.

The aim of the research is scientific justification for the basic parameters of the legal integration of the national social security systems in the EAEU, on the basis of global and regional processes in the world, the experience of realization of measures on social support of the population in the regions, primarily in the European Union.

\section{Forms and Mechanisms of Social Security in the EAEU}

The ongoing legal reforms in the EAEC states are primarily aimed at the implementation of constitutional guarantees and social orientation of public policy. Proof of this is enshrined in the national constitutions of proclamations of the EAEU stated being a welfare states. It should be noted, that the program documents of the UN on social protection of the population were included in the list of global problems of humanity. All this points to the urgency and relevance of social security rights, both within the internal policies and in the international arena.

Constitutional statements of the EAEU states as welfare states suggests that social legislation, social security guidelines are precisely those criteria by which to judge the real situation in the States, the degree of implementation of the proclaimed Constitutional rights and freedoms, values and priorities, correct guidelines, forms and methods of legal reforms. The constitutional principle of the welfare state assumes the obligation to serve the public good not only to public authorities and citizens, but also control over the observance of this principle in the framework of inter-state and international cooperation (Kladov, 2005; Kosenko, 2012; Kostenko \& Lavrenova, 1992). Compliance with the principles of international law in conjunction with the constitutional priorities is key to the successful development of the states. In this regard, a major focus is to comply with international standards. Most countries, recognizing the need, feasibility and mutually beneficial process of compliance and implementation in domestic law of international social standards, 
recognizes the existence of financial difficulties in providing national budgets with the highest international standards of social protection rights.

Features of harmonization of national and international law on the provision of social rights are in the specific performance guarantees of the rights in the domestic legal system. This is due to the fact that most of these international guarantees cannot be used directly, demanding complex legal and organizational measures with regard to national public relations, financial support in the implementation of social rights, the definition of domestic sources of financing, and measures to ensure their functioning. Mandatory financial security of the social rights causes a complex of measures in domestic law to set the funding sources, as well as measures to ensure their functioning. Despite the determination of general domestic application of international norms in the national law, the issue of the applicability of the specific rules in this sphere depends on regulatory guarantees of necessary social, financial and economic conditions for its implementation. The specifics of implementation of international standards of social security determines the possibility of their execution by the state only in given its successful economic reforms, the positive financial situation.

The collapse of the Soviet Union, in fact, the next day has determined the vital need to create new forms of regional integration, to look for ways and opportunities for cooperation in the economic, political, military and humanitarian aspects. Activation of labor migration between states needed appropriate legal regulation and institutional support.

The crucial importance for the given sphere of social relations is the Treaty between the Republic of Belarus, Republic of Kazakhstan, the Kyrgyz Republic and the Russian Federation on the deepening of integration in economic and humanitarian areas (March 29, 1996), which establishes that Parties conduct coordinated social policies, harmonize national social security systems, gradually equalize the levels of pension and benefits to veterans of war and labor, disabled people and low-income families. At the initial stage of CIS formation, the Statement of the Inter-parliamentary Assembly of CIS member states "On social protection of citizens", dated September 15, 1992, states that reforms and economic changes of CIS member state require new approaches and concerted action in the field of human rights and social protection of citizens. It recommended that the public authorities provide the citizens of the CIS states, who permanently reside in the territory of another CIS member-state, with the possibility to have social and economic rights as nationals, have equal legal protection. CIS members should ensure the formulation and implementation of a coherent social policy. As approved at the session of the CIS Interparliamentary Assembly on September 15, 1992, "Guidelines for the harmonization of national laws of the Commonwealth of Independent States" is fixed that one of the main areas in which it is advisable to CIS countries to carry out the convergence of national laws, are basic conditions for the movement of labor and guarantee labor and social rights of workers.

Later on, a significant number of bilateral and multilateral Treatys was signed among the CIS countries in the area of ensuring social rights. However, the existing objective problems of implementation of international instruments on social security in the national legislation did not allow to implement international standards. In this context, a fair conclusion is reached in the research of Velyaminov (2004) stating that given the conditions of the national interests of the CIS countries being focused on reorientation towards third countries, the lack of clear guidance in the construction of supranational bodies of the CIS, the lack of common reforms on harmonizing national legislations across the $\mathrm{CIS}$ members, has not been achieved. The differences in economic potential, starting conditions of integration, the pace and direction of reform, especially geographical location, had a significant role in this outcome.

At subsequent stages of development of Eurasian integration neither in part of the Eurasian Economic Community (EurAsEC) nor in the format of the Customs Union, the problem of efficiency of regional cooperation in the field of social security did not find its solution. It is in such adverse conditions, a process of legal integration of the EAEU in the field of social security has started. The legal basis of this process was the Treaty on the Eurasian Economic Union (Astana, May 29 , 2014) (hereinafter - the Treaty). According to this Treaty, the social security (i.e. social insurance, except pension) of workers of Member States and members of their families carried out under the same conditions and in the same manner as the citizens of the state of employment. An employment experience of the workers of the Member States shall be included in the total employment experience for the purposes of Social Security, except for retirement, in accordance with the laws of the state of employment. Pension provision of workers of Member States and members of their family is governed by the laws of the state of residence, as well as in accordance with a separate international treaty between Member States.

Currently, there is an active expert work on the drafting of an international treaty under the EAEU on pensions, unification of standards and forms of this type of social security. However, it is complicated by the fact that the pension systems of the states of the Union have evolved under individual ways that have nothing to do with each other. As a result, the creation of the EAEU had no common ground of social systems of the Union, which has the potential to generate social tensions and negative consequences for citizens. 
One of the main directions of development of the integration is to eliminate barriers to labor mobility. The absence or lack of a legal settlement of the issue of pension while working in other Member States of the Union is a limiting factor in the formation of a common labor market. Currently, the main difference are in the different approaches to financing the pension system and the distribution of pension funds. Problematic are the questions arising from the transfer and preservation of pension rights in the implementation of employment and relocation of citizens of the Member States EAEC from one country to another.

The social pension, state social disability benefits, benefits provided in case loss of a breadwinner will be granted and paid in accordance with the legislation of a Member State of the Eurasian Economic Union. It is assumed that the Treaty on pensions in the framework of the EAEU will enter into force on January 1, 2016, since a draft Treaty has been developed and passed the stage of coordination in the Member States. However, because of the fundamental difference in the approach to pension provision in the Union, the negotiations over the Treaty a complex and intense.

In our view, the main purpose of the Treaty should be the harmonization of the legal modalities of the pension systems of the Member States, which involves the following set of tasks:

- The strengthening and stabilization of the financial base of pension schemes;

- Development of legal mechanisms to guarantee the safety of the funds invested in private pension funds;

- Preventing the reduction of pension guarantees, set by the requirements of the International Labour Organization;

- Developing measures aimed at the gradual lifting of restrictions on the maximum size of pensions;

- Ensuring a gradual transfer of pension systems while working in special working conditions for professional and corporate pension systems, under the terms of the mandatory pension insurance.

A wide variety of rules and regulations on pensions, which are largely dependent on individual economic and demographic conditions of a particular state, determines the need for a substantive elaboration of the Treaty that could take into account modern trends of development of pension systems, recommendations of international organizations, the experience of other countries, as well as the specific conditions of the EAEU member states.

Beyond the Treaty are other types of social security and insurance, which migrant workers and their families have the rights of, as well as citizens with disabilities, the unemployed, the poor, families with children, persons who have lost their breadwinner, and many other categories of welfare recipients. The problem of social protection of citizens of the Union, carrying out labor activity outside the State of nationality, on receipt of disability, the occurrence of death due to an accident at work, remains unresolved, moreover, there are no documents about the intention of the EAEU to resolve this issue.

The major obstacle to the convergence of social welfare of the EAEU states are significant differences in national systems of social security. In view of the analysis of domestic legislation of the EAEU, it recommended to direct the legislative regulation of compulsory social insurance in the member states at development of a personalized account throughout the system of compulsory social insurance, to conceptually develop common approaches and principles for each area of insurance. Further harmonization of legislation on compulsory social insurance is recommended by the implementation into national laws and other legal acts of the recognized standards of the International Labour Organization. In addition, the harmonization of the laws of the EAEU in the field of social security should be directed towards: the development of common parameters to ensure the rights of migrant workers; the issues of social protection against social risks; the convergence of social protection based on 'traditional' reasons: disability (general and special); loss of the breadwinner; work in special conditions; birth of a child; living and working in areas exposed to environmentally adverse factors; the recognition of a large family and a few others.

Since the collapse of the USSR, modern countries of EAEU have chosen individual paths of development of social systems, identified the subjective sources of funding, which determines the inconsistency of the member states of the relevant areas of domestic policy, the lack of a common approach in shaping national legislation. It is a solution of these problems should be the focus of practical conclusions: firstly, increase in the efficiency of regional cooperation can be achieved, along with other mechanisms, through the adoption of legislation to facilitate the phased convergence of the regulatory framework of the member states in the field of social security, which include model laws. Secondly, the cooperation may be directed to the development and adoption of the conceptual regional acts that are recommended for use in the national legislation.

An example of the founding act on social rights in the framework of integration associations is the Charter of Fundamental Rights of the European Union (hereinafter - the Charter). The Charter embodies the concept of social guarantees of the European Union, independent of the primary-state citizenship. The document reveals the principle that EU citizens have rights and responsibilities inherent in their country, but complemented and defined by the European 
Union. Today, a single social policy of the EU is seen as a factor in the deepening of integration processes, components and elements of policies on the development and the search for a genuine European identity, designed to promote the harmonious and balanced development, economic and social cohesion of the community. This involves activation of such functions of the European Union, as coordination, harmonization, regulation, management, monitoring and support processes that promote effective disclosure of the potential of the EU, as well as a clear social orientation of its activities. Currently, a single social policy represents a vital element in the strengthening of internal connections of the Union and the European identity. Competencies possessed today by the institutions of social partnership, a variety of forms and levels of cooperation lead to a greater role for supranational regulation, the principle of the primacy of EU law over national law (Atkinson, 2002; Craig et al., 2007; Dashwood, 2004; Peers \& Ward, 2004; Kanunnikov, 2014; Kosenko \& Lavrenova, 1992; Margiev, 1999; Topornin, 1992).

Within the framework of the EAEU, such fundamental document is the Charter of social rights and guarantees of citizens of independent states of the CIS. Based on the analysis, we determine that the EAEU states do not fully ensure the social rights guaranteed by the Charter. These rights include: the right-guarantee for complete social security, regardless of place of residence, the full pension security in old age, sickness, disability, loss of breadwinner and in other domestic law of the cases, irrespective of the territory of the state the right for pensions is acquired, as well as the state benefits for families with children; the requirements for the social security system to provide financial and other assistance to dependent family members of the unemployed and people who lost the right to unemployment benefit due to the expiration of the deadline for its payment; position that temporary disability benefits shall be paid in the amount of not less than 60 per cent of the employee's earnings and its amount should not be less than the national statutory minimum wage; provisions on determining the amount of cash benefits for child care being not below the minimum wage set by the national legislation.

The most important area of cooperation among the EAEU member states in the field of social security should be the development and adoption of model laws (i.e. codes) that will lead to 'flexible' integration of the countries depending on the socio-economic conditions. The indicated direction of 'flexible' integration is, in our view, an effective way of execution of a state's international obligations, since the integration processes are often complex political, economic and social nature within the state. Model regulations should be the basic document on which to build the integration of interstate relations, developing national legal framework for ensuring social rights in the countries of the EAEU.

\section{Discussion and Conclusion}

The issues of social security and the needs of the population in social protection, resulting in the integration process, require the establishment of special institutions to ensure, on the one hand, the compliance of international obligations in the social sector taken by the state, on the other, the creation and consolidation of relevant recognized standards via the law-making. Despite the elaborated single international treaty in the field of pension regulation, the transition to a unified social regulation requires adjustment of the social legislation at the level of individual states, as well as to work together to determine a mutually acceptable social standards, monitoring their performance by the EAEU member states.

International legal cooperation in the field of social security within the framework of the EAEU should be aimed at providing a comprehensive solution of the following strategic objectives:

- Expanding economic integration determines the development of the social and labor integration of the EAEU, which must include the establishment of appropriate international legal framework, of a unified conceptual strategic document on the development of the EAEU in the social sphere, of the legal and organizational interaction of the countries to establish guarantees in the implementation of social rights;

- Convergence, harmonization of national legislation in the sphere of social protection of the population. The lack of a uniform approach to the legal regulation of social rights of citizens in the states of the Union leads to insecurity of mechanisms of the safeguards enshrined in relevant international obligations;

- Improving sub-national mechanisms for the implementation of international commitments into national law.

The area of the former Soviet Union objectively has three levels of integration and cooperation in the social and labor sphere. Regional acts in the framework of the CIS, sub-regional - in the framework of individual integration associations (e.g. EAEU), bidirectional, based on intergovernmental cooperation of individual states. At the same time, there is no clear mechanism for coordination and linking of international legal acts, adopted at various levels of cooperation and integration of the countries in the area of social protection. Under the conditions of the existence of diverse forms of international legal cooperation in the field of social security in the post-Soviet space, it is appropriate and practically significance to establish a clear and consistent communication and coordination between the existing international legal instruments. 
Coordination between the various legal forms of cooperation in the framework of the EAEU should, in our view, take place by determining the value of relevant multilateral and bilateral agreements on the one hand and model acts on the other. The most promising, in our view, is the development of model legislation, which refers to the so-called sources 'soft law', which enables to take into account the political, economic, social and institutional conditions of social standards as to even the standards of human rights.

The study is one of the first complex works of the issues relating to the integration of social welfare states of the Eurasian Economic Community. The paper considers the EAEU as the first successful integration and a real step in the construction of the post-Soviet space in the historical, political, economic and legal significance. Political, legal, and economic preconditions for further forms of integration in the Eurasian region stem from the very existence of the EAEU and its basic documents. The formation of union states should be based on an integrated approach, addressing the full range of issues in the process of integration. Common objectives, the geographical factor, the extent and depth of the interdependence of economic relations, mental closeness of the peoples and other reasons are included in the common factor leading to the integration of EAEU countries.

Social issues and needs, that arise in the integration process, require effective management, which has the organizational and legal problems. There is a requirement of appropriate mechanisms to resolve these issues, the presence of integration nterest, while maintaining the foundations of the national interests of the EAEU, the form and content of which depend on the scope of powers transmitted to supranational structures. National, 'integrational' and international interests must correspond on the general grounds contained in the transition to international regional social protection.

The treaty on pensions in the framework of the EAEU, agreements and decisions on the regulation of social protection, the transition to a common regulation of social rights of citizens of the EAEU assume the adjustment of social and related legislation at the level of a particular state, as well as the joint statement of the administration process of implementation of social security rights. In order to avoid restrictions and reduction of the rights in the social sphere requires complex unification of the relevant national legislation of the member states. Ongoing reforms in the states and economic changes require new approaches and concerted action in the field of human rights and social protection of citizens. It is recommended that EAEU public authorities provide citizens of the Union permanently residing in the territory of another State of the Union, with the equal legal protection on the use of social and economic rights as those provided to the nationals; to ensure the formulation and implementation of a coherent social policy. One of the main areas of convergence of the national laws could be the basic conditions for the movement of labor and guarantee of the labor and social rights of workers.

A further solution to the problems of improving the forms and methods of international legal cooperation and integration in the field of social security within the framework of the EAEU may be provided by addressing the following specific tasks: 1) increasing the efficiency of control over the international obligations of the member states in terms of implementation of the national legal system and the organization of the institutional system of guarantees of social rights; 2) ongoing development of the competence of the institutional system in the field of social security. This area is closely linked with the restriction of the sovereignty of the member states and should be used carefully; and 3) introduction of a coordinated social and legal policy, convergence, harmonization of national legislation in the field of social protection.

\section{References}

Abbott, F.M., Kaufmann, C., \& Cottier, T. (2006), International trade and human rights: foundations and conceptual issues. Michigan: University of Michigan Press.

Atkinson, A.B. (2002), Social indicators: The EU and social inclusion. Oxford: Oxford University Press.

Bogolyubova, Y., Nikolaeva, Yu.V., \& Pshenko, K.A. (2005), International humanitarian cooperation and the Commonwealth of Independent States. Moscow: Nauka.

Chernichenko, S.V. (1999), The theory of international law. Moscow: Izdatelstvo.

Costea, A.C. (2005), Regional Integration Highlights in 2004. [Online] Available: http://netris-acp.org (October 12, 2015).

Craig, P., De Burca, G., \& Craig, P.P. (2007), Human rights in the EU. EU Law: Text, Cases and Materials (4th ed.). Oxford: Oxford University Press.

Dashwood, A. (2004), The relationship between the member states and the European union / European community. Common Market Law Review, 41 (2), 1-12.

Frohwein, J.A. (2004), Analysis of the legal implications for States ratifying both the European Convention on Human Rights and its protocols and the Convention on Human Rights of the Commonwealth of Independent States (CIS). HRLJ, 17 (3-6), 23-37.

Kanunnikov, A.A. (2014), European Union - Latin America: economic, political, social cooperation: монографpuя. Moscow: Reports of the Institute of Europe RAS. 
Khamzin, A.Sh. (2009), The international legal framework for social and labor rights in the Republic of Kazakhstan. Astana: Nauchnoye izdatelstvo.

Khamzina, Zh.A., \& Khamzin, A.Sh. (2009), Problems of the state to ensure social rights in Kazakhstan: the constitutional and legal research. Astana: Nauchnoye izdatelstvo.

Kladov, A.Yu. (2005), Formation of the welfare state in the Russian Federation. Moscow: Academy of Labour and Social Affairs.

Kosenko, A.A., \& Lavrenova, I.V. (1992), On the issue of supranationality and features of EU law. European integration: legal issues, 1), 41-44.

Kosenko, O. (2012), The welfare state: foreign experience. Moscow: Academy of Labour and Social Affairs.

Lagutina, M. (2014), Eurasian Economic Union Foundation: Issues of Global Regionalization. Eurasian Border Review, 5(1), 95-111.

Langenhove, L.V., Torta, I., \& Costea, A.-C. (2006), The Ascent of Regional Integration. Brugge: UNU-CRIS. [Online] Available: http://www.southernaffairs.org/2008/04/new-and-old-regionalism-theories.html (October 12, 2015).

Linn, J. F., \& Tiomkin, D. (2005), Economic Integration of Eurasia: Opportunities and Chalenges of Global Significance. Warsaw: CASE.

Margiev, V.I. (1999), Some features of the domestic law of the European Communities. Jurisprudence, 1, 210-223.

Mishalchenko, Yu.V. (2004), The legal system of the Eurasian Economic Community and ways to improve it. International lawyer, 2 , 195-196.

Moiseev, E.G. (2001), Agreement on the establishment of the Eurasian Economic Community. International law, 4, $254-271$.

Peers, S., Ward, A, (2004), The EU Charter and of Fundamental Rights: politics, law and polity. Oxford: Hart Publishing.

Sharkov, Yu.M. (2004), The current situation and prospects of development of the CIS. Moscow: Russian Foreign Ministry Diplomatic Academy.

Shumilov, V.M. (2007), International labor and migration law of the CIS. Moscow: Book World.

Tikhomirov, Yu.A. (1996), Course of comparative law. Moscow: Nauka Press.

Topornin, B.N. (1992), European Union: law and institutions. Moscow: Izdatelstvo.

Velyaminov, G.M. (2004), International economic law and process. Textbook. Moscow: Wolters Kluwer. 